\title{
Fungal growth and in planta distribution of host-specific AAL-toxin in tomato plants infected with the tomato pathotype of Alternaria alternata
}

\author{
Ahmed A. Kheder ${ }^{1}$, Yasunori AKAgI ${ }^{2}$, Kazumi TAKAO ${ }^{2}$, Hajime AKAmatsu ${ }^{2,3}$ \\ and Motoichiro KoDAmA ${ }^{2,4 *}$ \\ ${ }^{1}$ The United Graduate School of Agricultural Sciences, Tottori University, 4-101 \\ Koyama-Minami, Tottori 680-8553, Japan \\ ${ }^{2}$ Faculty of Agriculture, Tottori University, 4-101 Koyama-Minami, Tottori 680-8553, Japan \\ ${ }^{3}$ Current address: Biological Resources Division, Japan International Research Center for Agricultural Sciences (JIRCAS), 1-1 \\ Ohwashi, Tsukuba, Ibaraki 305-8686, Japan \\ ${ }^{4}$ Fungus/Mushroom Resource and Research Center, Faculty of Agriculture, Tottori University, 4-101 Koyama-Minami, Tottori \\ 680-8553, Japan
}

\begin{abstract}
Summary
The tomato pathotype of Alternaria alternata causes Alternaria stem canker of tomato (Solanum lycopersicum L.) by producing a host-specific AAL-toxin. The chemical structure and biological activities of AAL-toxin are analogous to those of the mycotoxin fumonisin. Determination of pathogen development and toxin production in infected tomato plants is of prime importance for pathological evaluation and risk assessment of AAL-toxin. On a resistant cultivar, AAL-toxin and the pathogen were restricted to a small region surrounding only the initial inoculation site. On the other hand, widespread distribution of the toxin and the pathogen were detected in a susceptible cultivar. The pathological significance and contamination risk from the toxin were supported by the results of in planta production of the toxin in diseased tomato plants.
\end{abstract}

Key words : Alternaria alternata, Tomato, Solanum lycopersicum, AAL-toxin, fumonisin, in planta toxin production

(Received October 31, 2011; Accepted November 30, 2011)

\section{Introduction}

Alternaria alternata (Fries) Keissler is a ubiquitous fungus found on many kinds of plants and other substrata $^{1)}$. Some are necrotrophic fungal pathogens that produce host-specific toxins (HSTs), which cause necrotic cell death only on susceptible plant cultivars during compatible interactions ${ }^{2,3}$. HSTs are reported to be critical determinants of pathogenicity or virulence in several plant-pathogen interactions ${ }^{2,3}$. The tomato pathotype of A. alternata (syn. A. alternata f. sp. lycopersici, syn. A. arborescens), which produces hostspecific AAL-toxin, causes Alternaria stem canker on susceptible tomato cultivars ${ }^{3-6)}$. The structure of AAL-toxins, which are chemical analogues of the mycotoxin fumonisins produced by Fusarium verticillioides (formerly F. moniliforme), has already been determined ${ }^{7-9}$. AAL-toxins consist of a family of struc-

\footnotetext{
*Corresponding author: M. Kodama, Faculty of Agriculture, Tottori University, 4-101 Koyama-Minami, Tottori 680-8553, Japan Tel: +81-857-31-5364; fax: +81-857-31-5364, E-Mail: mk@muses.tottori-u.ac.jp
} 
turally analogous metabolites, and AAL-toxin $\mathrm{T}_{\mathrm{A}}$ is the major toxin ${ }^{7-9}$. AAL-toxin and fumonisin are sphinganine-analogue mycotoxins (SAMs) which induce apoptotic cell death in susceptible tomato cells and mammalian cells by inhibiting ceramide biosynthesis ${ }^{7,10-12)}$. In A. alternata-tomato interactions involving the tomato pathotype, a major factor in pathogenicity is the production of the host-specific AAL-toxin that is capable of inducing cell death only in susceptible cultivars ${ }^{13-15)}$.

In planta production of phytotoxins is an important system for evaluating the pathological roles of toxins $^{16,17)}$. Nevertheless, production of toxins in infected plant tissues has not been proven for many phytotoxins, including HSTs, although in vitro toxin production on artificial media has been demonstrated in many cases $^{17}$. The reason for difficulties in the detection and quantification of toxins in planta, especially in the case of HSTs, is that the concentration of the toxins in vitro is generally very low. Because HSTs have high toxic activities, only a slight amount of these toxins is enough to exert a toxic effect against host cells during infection by the toxin-producing pathogens ${ }^{16,17)}$. Therefore, rapid and highly sensitive methods for quantitative determination of toxins in diseased plant tissues have been in demand. High-performance liquid chromatography (HPLC) has improved the analysis and quantification of many HSTs ${ }^{15,17,18)}$. An improved HPLC method $^{18)}$ was developed for the detection and quantification of AAL-toxins by precolumn fluorescence derivatization with $o$-phthalaldehyde (OPA) plus mercaptoethanol, with a detection limit of $1 \mathrm{ng}^{18}$. This method offers apparent advantages over maleylation and UV detection of the toxins ${ }^{1920)}$, because prechromatographic derivatization of the toxin with OPA is rapid and easy, and fluorescent derivatives permit excellent detection sensitivity.

Here, the improved HPLC method was used to examine in planta production of AAL-toxin and localization of the pathogen in infected tomato plants to evaluate the pathological significance of the toxin during the infection process. In addition, it is important to evaluate AAL-toxin production in diseased tomato tissues, because biological activities of AAL-toxin is similar to those of fumonisin mycotoxins produced by Fusarium (Gibberella) species ${ }^{7,10,11)}$ and contamination of crops by AAL-toxin might have potential risk in humans.

\section{Materials and Methods}

Fungal strains and culture conditions Strain As- $27^{20)}$ of the tomato pathotype of A. alternata (syn. A. alternata f. sp. lycopersici, syn. A. arborescens) and the transformant derived from this isolate were used. Both isolates were maintained on potato dextrose agar (PDA) (Difco, Detroit, MI) slants or as mycelial fragments in $20 \%$ glycerol at $-80^{\circ} \mathrm{C}$. The isolates were cultured on V8 juice agar medium for production of conidia or in potato dextrose broth (PDB) (Difco, Detroit, MI) for genomic DNA preparation.

Generation of the marker strain Protoplasts were prepared from the A. alternata tomato pathotype As-27 strain as described previously ${ }^{13)}$ except that $10 \mathrm{mg} / \mathrm{mL}$ of lysing enzyme (Sigma-Aldrich, St. Louis, MO) and $10 \mathrm{mg} / \mathrm{mL}$ of kitalase (Wako Pure Chemicals, Osaka, Japan) replaced the enzymes originally used. Protoplasts $\left(1 \times 10^{7}, 80 \mu \mathrm{l}\right)$ were transformed with pAN7-1 ${ }^{21)}$ to confer resistance to hygromycin B by methods described previously ${ }^{13)}$. Integration of the hygromycin B resistance gene ( $h p h$ ) cassette was determined by $\mathrm{PCR}^{13,22)}$. The hygromycin B-resistant transformant (A-63) of As-27 was purified by single spore isolation and was used as the marker strain for inoculation tests. 
Inoculation of the marker strain onto tomato plants

For inoculation with the pathogen, tomato (Solanum lycopersicum L.) plants either susceptible (cv. 'Earlypak 7') or resistant (cv. 'Ace') to the tomato pathotype of A. alternata were grown in sterilized soil in a growth chamber (Growth Cabinet MLR-350, Sanyo, Osaka, Japan) at $24-26{ }^{\circ} \mathrm{C}$ with a photoperiod of $14-16 \mathrm{~h}$ (6,000 lux). The tomato plants at 4-6 weeks of age were inoculated with the hygromycin B-resistant transformant (A-63) of As-27 as follows. The surface of the basal portions of stems of susceptible and resistant tomatoes grown in pots were lightly scratched with a needle, and small pieces of mycelial plug from PDA cultures of the pathogen were put directly on the wounded stems. The inoculation site was covered with moist paper and Parafilm ${ }^{\circledR}$ M (SPI Supplies/Structure Probe, Inc., West Chester, PA), and the plants were placed in a growth chamber at $24-26{ }^{\circ} \mathrm{C}$ for given incubation periods.

Detection of the pathogen and quantification of AAL-toxin in planta At days 7 and 20 of post-inoculation, serial sections were prepared from the infected stems as described in Figure 1, and distributions of the pathogen and the toxin were determined. Each stem section consisted of a $1 \mathrm{~cm}$-long stem tip except section No. 7, which consisted of the entire plant including stems and leaves, and section No. 0, which included only the inoculation site (Fig. 1). Each stem section was divided into two parts, and one of the parts was placed on the selective PDA medium containing hygromycin B (100 $\mu \mathrm{g} / \mathrm{ml}$; Wako Pure Chemical, Osaka, Japan) for selective detection of the inoculated marker strain, while the other of the parts was immersed in ethanol for $24 \mathrm{~h}$ at $4{ }^{\circ} \mathrm{C}$ for extraction of the toxin. Quantitative analysis of AAL-toxin $\mathrm{T}_{\mathrm{A}}$ in the section was performed by HPLC with precolumn derivatization of $o$-phthalaldehyde as described previously ${ }^{15,18)}$.

\section{Results and Discussion}

An antibiotic-resistant marker strain of $A$. alternata (A-63) was used to reisolate and detect the inoculated fungus in infected plant tissues and select against other fungal contaminants. The marker strain A- 63 carrying the $h p h$ gene produces equilibrate amount of AAL-toxin during cultures. The basal portions of stems of the tomatoes were inoculated with A-63. The reason for this choice of inoculation site is that natural infection by the pathogen reportedly initiates at the basal region of the stem (between stem and root) of tomato plants ${ }^{4,5)}$. The stem canker symptom appeared on the stems of the susceptible cultivar after 7 days of incubation. On the other hand, almost no symptoms were observed on the resistant cultivar.

Serial sections were prepared from the infected

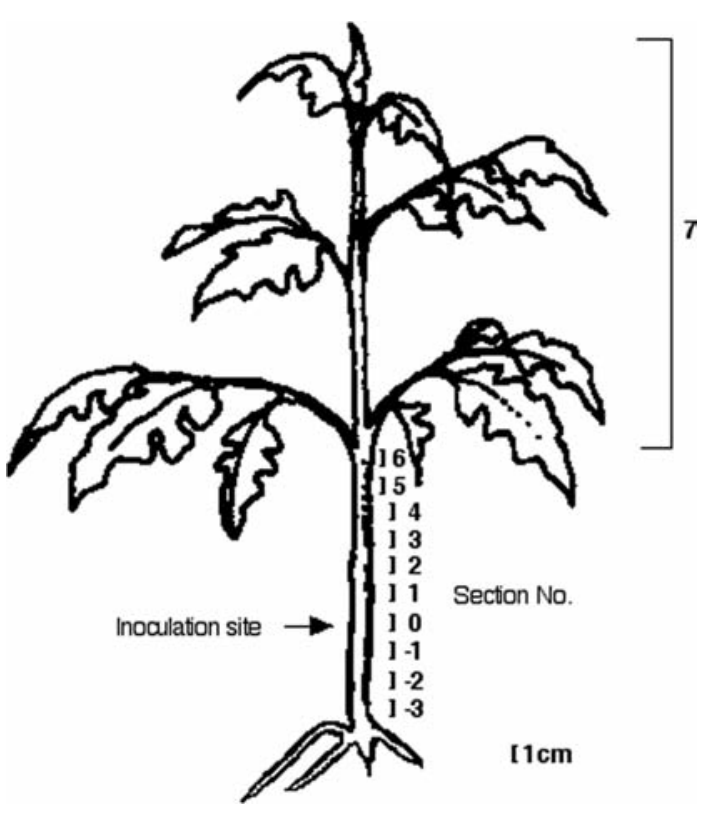

Fig. 1. Diagram of sectioning procedure used for evaluating in planta distribution of the pathogen and AAL-toxin in infected tomato plants. Each stem section consists of a one cm-long stem tip, except for section No. 7 , which consists of the entire plant including stems and leaves. Section No. 0 includes the pathogen inoculation site. 
stems as described in Fig. 1 at 7 and 20 days after inoculation, and distribution of the pathogen and the toxin was determined. To examine the distribution of the pathogen, fungal growth from sections bearing fungal invasion was observed on the selective medium (Fig. 2 ). The growing hyphae were transferred to fresh selective media to confirm drug resistance of the isolated fungi. The maintenance of the marker gene in the isolated strains was confirmed using PCR with primer pairs for $h p h$ as described previously ${ }^{12)}$ (data not shown). After 7 days of inoculation, fungal growth and AAL-toxin production on the resistant cultivar Ace were restricted to only the inoculated stem section (section 0 ) (Table 1 ). However, the pathogen and the toxin were detected in the inoculated stem section (0) and the adjacent section (1) on the susceptible cultivar Earlypak 7 (Table 1). The pathogen and toxin were both restricted to the inoculated section ( 0 ) even 20 days after inoculation on the resistant tomato (Table 1 ). On the other hand, the pathogen and the toxin were widely distributed (sections -2 to 4 ) in the susceptible cultivar 20 days after inoculation (Table 1 ), and AAL-toxin was diffusing to upper portions of the plant beyond the fungal growing area (sections 0 to 5 ). The pathogen was reisolated at lower parts (sections -2 to -1 ) of the stem without the toxin. In these sections, toxin production might be below the detection limit due to the relatively reduced growth rate of the pathogen.

Thus, in planta production and release of the toxin by the pathogen were confirmed in this study using the combination of

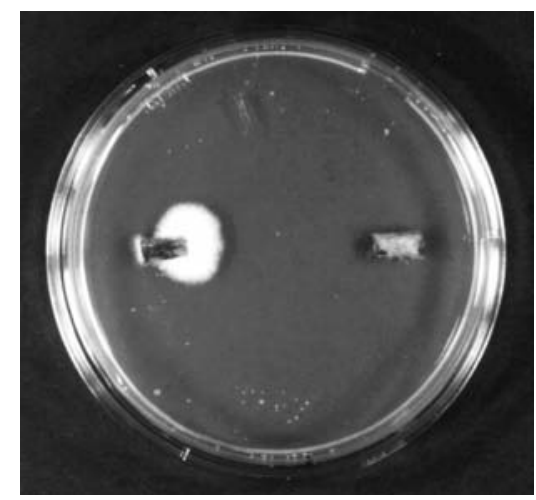

Fig. 2. Growth of the inoculated marker strain (A-63) of the tomato pathotype of Alternaria alternata on PDA plate containing hygromycin B ( $100 \mu \mathrm{g} /$ $\mathrm{ml}$ ). Mycelial growth was observed after 5 days of incubation on the left stem section, indicating distribution of the inoculated marker strain on this stem section. The right stem section does not contain the marker strain.

Table 1. Fungal growth and in planta distribution of AAL-toxin in tomato plants infected with the tomato pathotype of Alternaria alternata

\begin{tabular}{|c|c|c|c|c|c|c|c|c|c|c|c|c|}
\hline \multirow{3}{*}{$\begin{array}{l}\text { Days after } \\
\text { inoculation }\end{array}$} & \multirow{3}{*}{ Plant } & \multicolumn{11}{|c|}{ Fungal growth and AAL-toxin production (ng/g fr. wt.) } \\
\hline & & \multicolumn{11}{|c|}{ Section number $^{\mathrm{d}}$} \\
\hline & & -3 & -2 & -1 & 0 & 1 & 2 & 3 & 4 & 5 & 6 & 7 \\
\hline 7 & Ep $7^{\mathrm{a}}$ & $\begin{array}{l}N^{b} \\
(-)^{c}\end{array}$ & $\begin{array}{l}\text { ND } \\
(-)\end{array}$ & $\begin{array}{l}\text { ND } \\
(-)\end{array}$ & $\begin{array}{c}71 \\
(+)\end{array}$ & $\begin{array}{c}35 \\
(+)\end{array}$ & $\begin{array}{l}\text { ND } \\
(-)\end{array}$ & $\begin{array}{l}\text { ND } \\
(-)\end{array}$ & $\begin{array}{l}\text { ND } \\
(-)\end{array}$ & $\begin{array}{l}\text { ND } \\
(-)\end{array}$ & $\begin{array}{l}\text { ND } \\
(-)\end{array}$ & $\begin{array}{l}\text { ND } \\
(-)\end{array}$ \\
\hline 20 & Ep7 & $\begin{array}{l}\text { ND } \\
(-)\end{array}$ & $\begin{array}{l}\mathrm{ND} \\
(+)\end{array}$ & $\begin{array}{l}\mathrm{ND} \\
(+)\end{array}$ & $\begin{array}{l}108 \\
(+)\end{array}$ & $\begin{array}{l}150 \\
(+)\end{array}$ & $\begin{array}{l}213 \\
(+)\end{array}$ & $\begin{array}{l}242 \\
(+)\end{array}$ & $\begin{array}{c}93 \\
(+)\end{array}$ & $\begin{array}{l}107 \\
(-)\end{array}$ & $\begin{array}{c}67 \\
(-)\end{array}$ & $\begin{array}{c}61 \\
(-)\end{array}$ \\
\hline 7 & Ace & $\begin{array}{l}\text { ND } \\
(-)\end{array}$ & $\begin{array}{l}\text { ND } \\
(-)\end{array}$ & $\begin{array}{l}\text { ND } \\
(-)\end{array}$ & $\begin{array}{l}139 \\
(+)\end{array}$ & $\begin{array}{l}\text { ND } \\
(-)\end{array}$ & $\begin{array}{l}\text { ND } \\
(-)\end{array}$ & $\begin{array}{l}\text { ND } \\
(-)\end{array}$ & $\begin{array}{l}\text { ND } \\
(-)\end{array}$ & $\begin{array}{l}\text { ND } \\
(-)\end{array}$ & $\begin{array}{l}\text { ND } \\
(-)\end{array}$ & $\begin{array}{l}\text { ND } \\
(-)\end{array}$ \\
\hline 20 & Ace & $\begin{array}{l}\text { ND } \\
(-)\end{array}$ & $\begin{array}{l}\text { ND } \\
(-)\end{array}$ & $\begin{array}{l}\text { ND } \\
(-)\end{array}$ & $\begin{array}{c}62 \\
(+)\end{array}$ & $\begin{array}{l}\mathrm{ND} \\
(-)\end{array}$ & $\begin{array}{l}\mathrm{ND} \\
(-)\end{array}$ & $\begin{array}{l}\text { ND } \\
(-)\end{array}$ & $\begin{array}{l}\text { ND } \\
(-)\end{array}$ & $\begin{array}{l}\text { ND } \\
(-)\end{array}$ & $\begin{array}{l}\text { ND } \\
(-)\end{array}$ & $\begin{array}{l}\text { ND } \\
(-)\end{array}$ \\
\hline
\end{tabular}

${ }^{\mathrm{a}} \mathrm{cv}$. 'Earlypak 7'.

${ }^{\mathrm{b}}$ Amount (ng/g fr. wt.) of AAL-toxin $\mathrm{T}_{\mathrm{A}}$ was determined by HPLC with OPA derivatization. ND: not detected.

${ }^{c}+$; The inoculated marker strain was reisolated from each section on the selection medium. - ; No fungus was reisolated from sections on the selection medium.

${ }^{\mathrm{d}}$ The section number is indicated in Fig. 1. 
a marker strain and a sensitive toxin detection method. As defined by Dimond and Waggoner ${ }^{23)}$, slightly modified by Dimond ${ }^{24)}$, candidate compound must meet the following criteria to be classified as a vivotoxin: (1) isolated from a diseased plant but not present in healthy plants; (2) chemically characterized ; and (3) produce all or some of the symptoms when applied to a healthy plant as a pure compound. AAL-toxin meets these requirements of a vivotoxin, and the pathological significance of the toxin has been further supported by these results on in vivo production of the toxin in diseased tomato plants.

At early stages of infection, no difference in pathogen growth and toxin production between the susceptible and resistant tomatoes was observed, whereas the pathogen continued to grow and extensively produce toxin in susceptible plants only. The widespread distribution of this toxin in diseased tomato might be the reason for symptoms of the disease that typically appear, such as dark brown cankers on stems and interveinal necrosis on the leaves ${ }^{4,520)}$. On a resistant cultivar, the pathogen was restricted to the initial infection site, although the pathogen was still alive at the later stages (20 days after inoculation) of infection. These findings suggest that the mechanisms of resistance to infection with A. alternata in tomato may be fungistatic rather than fungicidal. In addition, AAL-toxin was still recovered from the resistant cultivar at later stages of infection. Thus, toxin degradation or detoxification may not be the mechanism of resistance as opposed to the case of HC-toxin, which, in the interaction between maize and Cochliobolus carbonum race 1, is inactivated by a reductase ${ }^{25}$. Insensitivity to AAL-toxin and fumonisin is conferred by the Asc1 (Alternaria stem canker resistance gene 1) gene, a homologue of the yeast longevity assurance gene, Lag1, which mediates resistance to SAM-induced apoptosis via production of alternative ceramide ${ }^{11)}$. Mechanisms of resistance to A. alternata infection in tomato, including signal transduction and expression of defense-related genes, are currently being studied in our laboratory ${ }^{26,27)}$.

\section{Acknowledgements}

We are grateful to H. Otani and M. Egusa for helpful discussions. We gratefully acknowledge R. P. Oliver for providing pAN7-1, and T. L. Peever and D. G. Gilchrist for providing Alternaria strains. This work was supported by Grant-in-Aid for Scientific Research from the Japanese Society for Promotion of Sciences, and Global COE Program “Advanced Utilization of Fungus/Mushroom Resources for Sustainable Society in Harmony with Nature”, MEXT, Japan.

\section{References}

1 ) Rotem, J.: The Genus Alternaria: Biology, Epidemiology, and Pathogenicity, (1994), APS Press, St. Paul, MN, USA

2 ) Kohmoto, K., Otani, H., Tsuge, T.: "Pathogenesis and host specificity in plant diseases: Histopathological, biochemical, genetic and molecular bases, Vol. II, Eukaryotes” (eds. Kohmoto, K., Singh, U.S., Singh, R.P.), pp. 51-63 (1995), Pergamon, Elsevier, Oxford, UK

3 ) Thomma, B.P.H.J.: Mol. Plant Pathol., 4, 225-236 (2003)

4 ) Gilchrist, D.G., Grogan, R.G.: Phytopathology, 66, 165-171 (1976)

5 ) Kohmoto, K., Verma, V.S., Nishimura, S., Tagami, M. Scheffer, R.P.: J. Fac. Agric. Tottori Univ., 17, 1-8 (1982) 
6 ) Peever, T.L., Su, G., Carpenter-Boggs, L. Timmer, L.W.: Mycologia, 96, 119-134 (2004)

7 ) Gilchrist, D.G., Wang, H., Bostock, R.M.: Can. J. Bot., 73, S459-S467 (1995)

8 ) Bottini A.T., Gilchrist D.G.: Phytotoxins I. Tetrahedron Lett., 22, 2719-2722 (1981)

9 ) Bottini A.T., Bowen J.R., Gilchrist D.G.: Tetrahedron Lett., 22, 2723-2726 (1981)

10) Wang W., Jones C., Ciacci-Zanella J., Holt T., Gilchrist D.G., Dickman M.B.: Proc. Natl. Acad. Sci. USA, 93, 3461-3465 (1996)

11) Wang, H., Li, J., Bostock, R.M., Gilchrist, D.G.: Plant Cell, 8, 375-391 (1996)

12) Spassieva, S.D., Markham, J.E., Hille, J.: Plant J., 32, 561-572 (2002)

13) Akamatsu, H., Itoh, Y., Kodama, M., Otani, H., Kohmoto, K.: Phytopathology, 87, 967-972 (1997)

14) Brandwagt, B.F., Mesbah, L.A., Takken, F.L.W., Laurent, P.L., Kneppers, T.J.A., Hille, J., Nijkamp, H.J.J.: Proc. Natl. Acad. Sci. USA, 97, 4961-4966 (2000)

15) Yamagishi, D., Akamatsu, H., Otani, H., Kodama, M.: J. Gen. Plant Pathol., 72, 323-327 (2006)

16) Kohmoto, K., Otani, H.: Experientia, 47, 755-764 (1991)

17) Kohmoto, K.: “Modern Methods of Plant Analysis, New Series. Vol. 13” (eds. Linskens, H.F., Jackson, J.F.), pp. 51-73 (1992), Springer-Verlag, Berlin, Germany

18） Kodama, M., Otani, H., Kohmoto, K.: Ann. Phytopathol. Soc. Jan, 61, 477-480 (1995)

19) Siler, D.J., Gilchrist, D.G.: J. Chromatogr., 238, 167-173 (1982)

20) Siler, D.J., Gilchrist, D.G.: Physiol. Plant Pathol., 23, 265-274 (1983)

21) Punt, P.J., Oliver, R.P., Dingemanse, M.A., Pouwels, P.H., van den Hondel, C.A.M.J.J.: Gene, 56, 117-124 (1987)

22) Akagi, Y., Taga, M., Yamamoto, M., Tsuge, T., Fukumasa-Nakai, Y., Otani, H., Kodama, M.: J. Gen. Plant Pathol., 75, 101-109 (2009)

23) Dimond, A.E., Waggoner, P.E.: Phytopathology, 43, 229-235 (1953)

24) Dimond, A.E.: Ann. Rev. Plant Physiol., 6, 329-350 (1955)

25) Johal, G.S., Briggs, S.P.: Science, 258, 985-987 (1992)

26) Egusa, M., Akamatsu, H., Tsuge, T., Otani, H., Kodama, M.: Pysiol. Mol. Plant Pathol., 73, 67-77 (2009)

27) Egusa, M., Ozawa, R., Takabayashi, J., Otani, H., Kodama, M.: Planta, 229, 965-976 (2009) 
トマトアルターナリア茥枯病菌が感染したトマト植物組織内における病原菌および宿主特異的

\section{AAL 毒素の分布}

Ahmed A. KHEDER：鳥取大学大学院連合農学研究科（680-8553 鳥取市湖山町南 4-101）

赤木靖典, 高尾和実, 赤松 創, 児玉基一朗 : 鳥取大学農学部（680-8553 鳥取市湖山町南 4-101）

児玉基一朗 : 鳥取大学農学部附属菌類きのこ遺伝資源研究センター（680-8553 鳥取市湖山町南 4-101）

赤松 創：現独立行政法人国際農林水産業研究センター（305-8686 つくば市大わし 1-1）

Alternaria alternata tomato pathotype は, 宿主特異的 AAL 毒素生産によりトマトアルターナリア茎枯病を 引き起こす. AAL 毒素はマイコトキシン フモニシンの構造類縁体であり, その生物活性も類似する. 罹病 植物組織内に掩ける病原菌の伸長と産生された毒素の確認は, 毒素の病理学的重要性とリスクの評価のた めに重要である。抵抗性植物品種上において, 病原菌㧍よび毒素は接種部位のみに局在していた。一方, 感受性品種上では, 毒素の広範な分布と病原菌の伸長が確認された. 本研究の結果から, AAL 毒素の病理 学的重要性が確認されるとともに, 䍜病トマトにおける毒素による污染リスクの可能性が示唆された.

キーワード : Alternaria alternata, トマト, Solanum lycopersicum, AAL 毒素, フモニシン, 罹病植物内毒素 産生 